\title{
A new genus and species of Tricorythidae (Ephemeroptera : Pannota) from Madagascar
}

\author{
W.P. McCafferty 1 \\ T.-Q. Wang 1
}

Keywords : Tricorythidae, Madagascar, Provonshaka, new genus, Manohyphella.

\begin{abstract}
Newly discovered mayflies from Madagascar have proven to represent a new genus and species of Tricorythidae. Provonsha$k a \mathrm{n}$. gen. is described in the larval stage, and compared with the Madagascar genus Manohyphella, which is also shown to be a member of the Tricorythidae. Provonshaka is a member of a phylogenetic lineage that also contains Manohyphella and the southeast Asia genus Teloganella. There are presently three tricorythid genera present in Madagascar, including the distantly related Tricorythus. Provonshaka thomasorum n.sp. is described from three rivers in Madagascar and is sometimes found cohabiting with Manohyphella keiseri. A diagnostic table giving the differences between Provonshaka and Manohyphella is provided.
\end{abstract}

Un genre nouveáu et une espèce nouvelle de Tricorythidae (Ephemeroptera : Pannota) de Madagascar

Mots clés : Tricorythidae, Madagascar, Provonshaka, genre nouveau, Manohyphella.

Des éphémères malgaches récemment découverts appartiennent à un genre nouveau et à une espèce nouvelle de Tricorythidae. Provonshaka n.gen. est décrit à l'état larvaire, et est comparé au genre malgache Manohyphella, dont l'appartenance aux Tricorythidae est aussi prouvée. Provonshaka fait partie d'une lignée phylogénétique comprenant aussi Manohyphella et le genre Teloganella d'Asie du Sud-Est. Trois genres de Tricorythidae sont actuellement connus de Madagascar, y compris le genre plus éloigné Tricorythus. Provonshaka thomasorum n.sp. est décrite de trois rivières malgaches et peut cohabiter avec Manohyphella keiseri. Une table de diagnose résumant lès cäractères différentiels entre Provonshaka et Manohyphella est présentée.

\section{Introduction}

To date, the only Tricorythidae of record from Madagascar has been Tricorythus Eaton, which was treated as Neurocaenis by Demoulin (1968). We recently received a gift of Madagascar specimens from Dr. George Edmunds that contained material of a new genus and species of Tricorythidae that we describe herein. In addition, we received paratypes of Manohyphella keiseri Allen, a genus and species described from Madagascar and placed in the family Ephemerellidae by Allen (1973). Our study showed Manohyphel-

1. Department of Entomology, Purdue University, West Lafayette, IN 47907, U.S.A. $l a$ is closely related to the new genus and to the genus Teloganella Ulmer from southeast Asia. The larva and adult of Teloganella were recently described by Wang et al. (1995). Together, the new genus, Manohyphella, and Teloganella appear to represent a distinct lineage within what traditionally has been known as the family Tricorythidae. We do not yet know of any representative of this particular lineage in southern Africa.

\section{Provonshaka n.gen. : description}

\section{Mature larva}

Body (Fig. 1) densely covered with robust microtrichiae. Frontal and lateral margins of head ; lateral margins of thorax, legs, and abdomen ; and outer lateral margins of operculate gills fringed with long hairlike setae. 


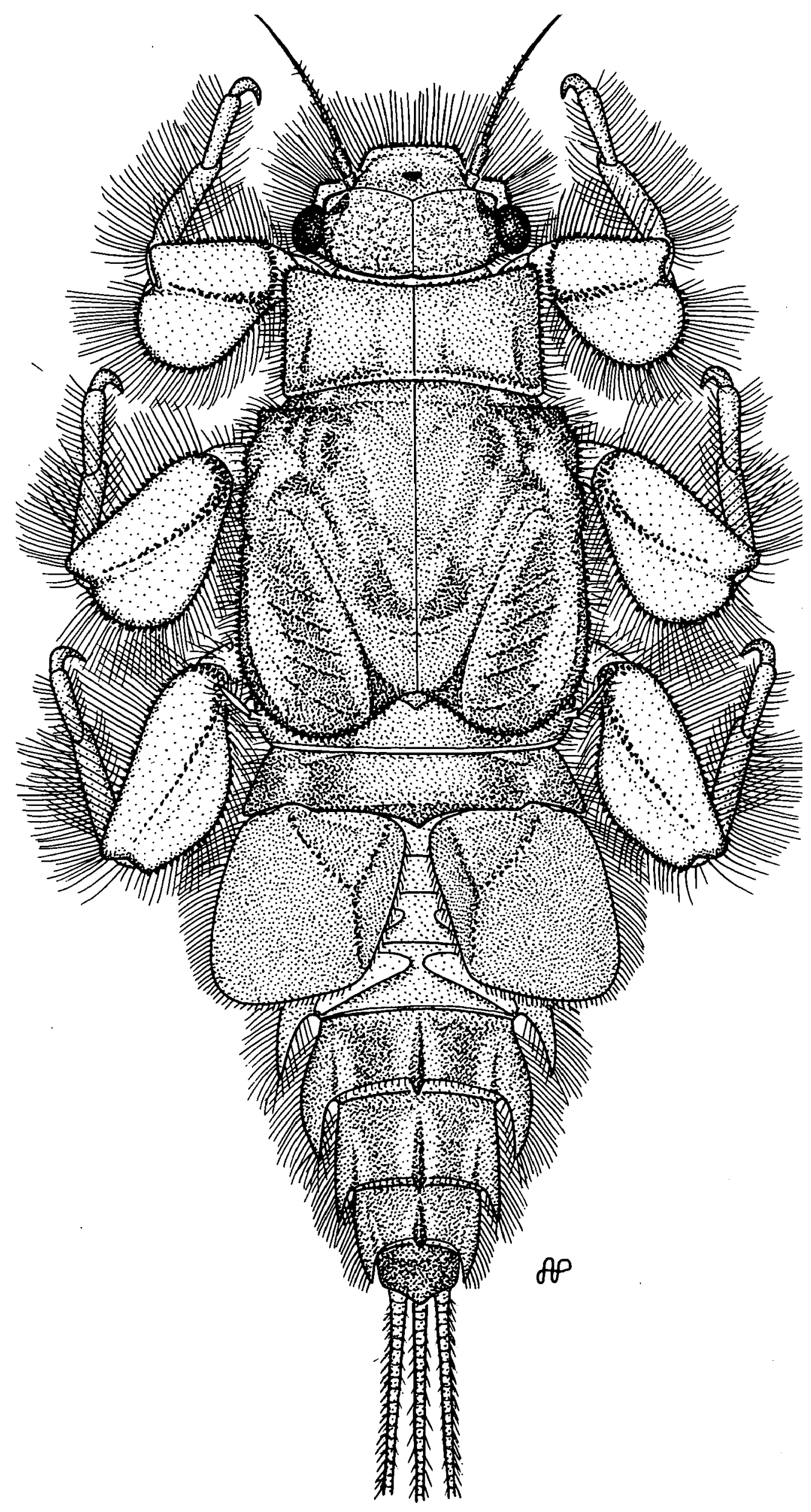

Fig. 1. Dorsal view of Provonshaka thomasorum n.gen., n.sp. : larva holotype. Fig. 1. Provonshaka thomasorum n.gen., n.sp. : larve holotype en vue dorsale. 
Maxillae (Fig. 2) narrow-elongate and lacking palps.

Labium (Fig. 3) with three-segmented palps. All palp segments subequal in length ; palp segment 1 broader than segments 2 and 3.

Femora (Fig. 1) well developed, with broad convex margin posteriorly (most produced in forelegs) ; lateral margins with long hairlike setae and small spines ; dorsal surface with median row of spinelike setae, continuing anterobasally.

Tarsal claws lacking denticles.

Gills (Figs. 1, 4-8) present on abdominal segments 1-6. Gills 1 (Fig. 4) consisting of single filament with hairlike setae. Gills 2 (Fig. 5) operculate, more-or-less quadrate, with $Y$-shape dorsal ridge in medial area of gills. Gills 3-6 (Figs. 1, 6-8) generally hidden from dorsal view by operculate gills, lacking marginal filaments, and oriented medially (Fig. 1).

Abdominal segments (Figs. 1, 9, 10) with posterolateral projections well developed on segments 2,6 , and 7 ; variously less developed on segments 5,8 , and 9 (Figs. 9, 10).

Egg : Polar caps absent.

Alate stages : Unknown.

\section{Type species}

\section{Provonshaka thomasorum McCafferty and Wang} n.sp.

\section{Generic etymology}

The generic nomen is an arbitrary combination of letters (with a Latin feminine ending) that incorporates the surname of our colleague and renowned scientific illustrator Arwin Provonsha.

\section{Diagnosis}

Provonshaka is somewhat similar to the Madagascar genus Manohyphella. Even though we have found the two genera cohabiting in the Tsaratango River, they can easily be told from each other in the larval stage by the characters given in Table 1. The Adults of Provonsha$k a$ remain unknown at this time. It is possible that the hindwings of Provonshaka are either entirely absent or smaller than the very small hindwings of Manohyphella. However, we were unable to distinguish any moveable flap on the larval metathorax of Provonshaka larvae, whereas a minute flap can be located on the metathorax of Manohyphella (and also Teloganella), both of which have relatively small hindwings as adults.

\section{Provonshaka thomasorum n.sp. : des- cription}

\section{Mature larva}

Body (Fig. 1) 5.0-6.0 mm. Caudal filaments $2.5-3.0$ $\mathrm{mm}$. General color ranging from light brown to dark brown.

Head capsule (Fig. 1) lacking tubercles and projections. Antennae approximately one and one half times length of median head capsule length ; flagella with minute hairlike intersegmental setae. Compound eyes relatively small and widely separated (both sexes).

Galealaciniae (Fig. 2) acute apically, with row of pectinate bristlelike setae apicomedially and tuft of hairlike setae apicolaterally.

Labium (Fig. 3) with densely setose glossae and paraglossae and apical palp segment only sparsely setose.

Pronotum (Fig. 1) three times as wide as long, and lacking tubercles.

Table 1. Differential characteristics of the larvae of the Madagascar genera Provonshaka and Manohyphella.

Tableau 1. Caractères différentiels des larves des genres de Madagascar Provonshaka et Manohyphella.

\begin{tabular}{lcc}
\hline Character & Provonshaka & Manohyphella \\
\hline Labial palps & subequal & 3rd segment shorter \\
Femoral armature & hairs and spines & hairs only \\
Claw denticles & absent & present \\
Head marginal setae & very long & very short \\
Operculate gills & wider than long & longer than wide \\
Gills 6 & present & absent \\
Abdominal median tubercles & on terga 2, 6-9 & on terga 3-8. \\
Abdominal posterolateral projections & on terga 2,5-9 & on terga 2-9
\end{tabular}



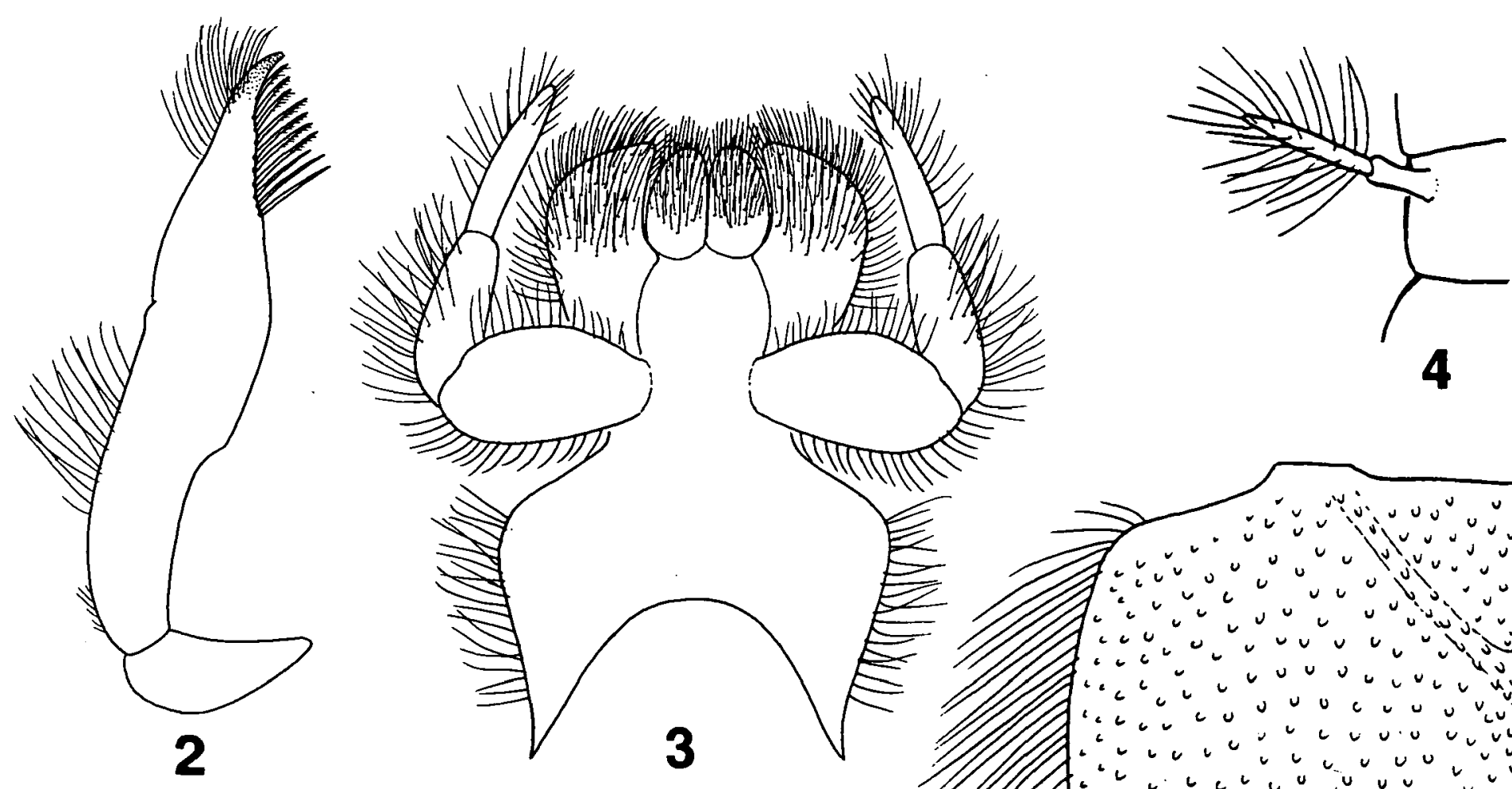

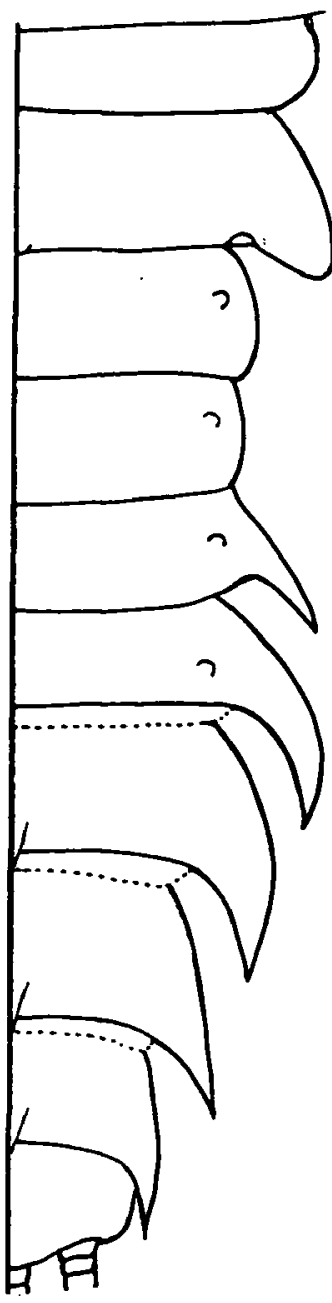

9

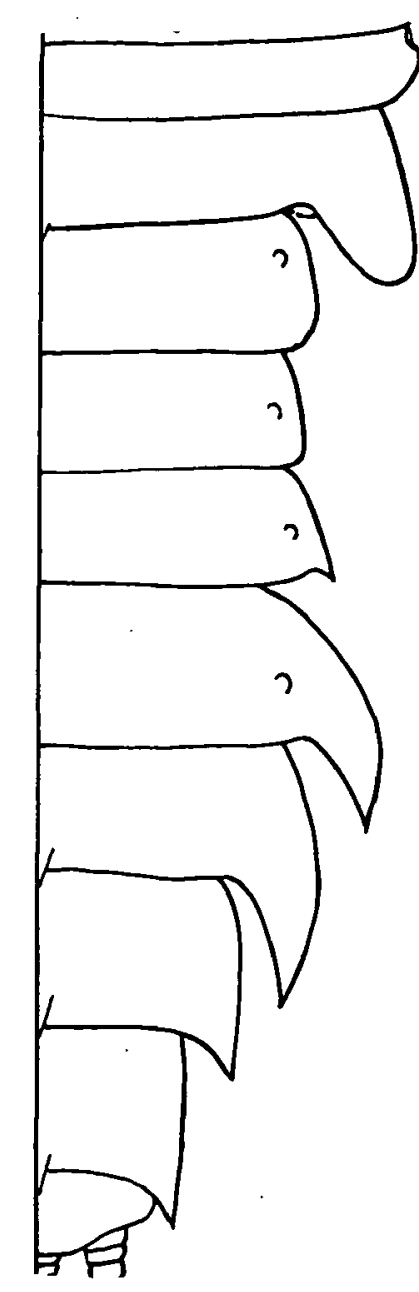

10
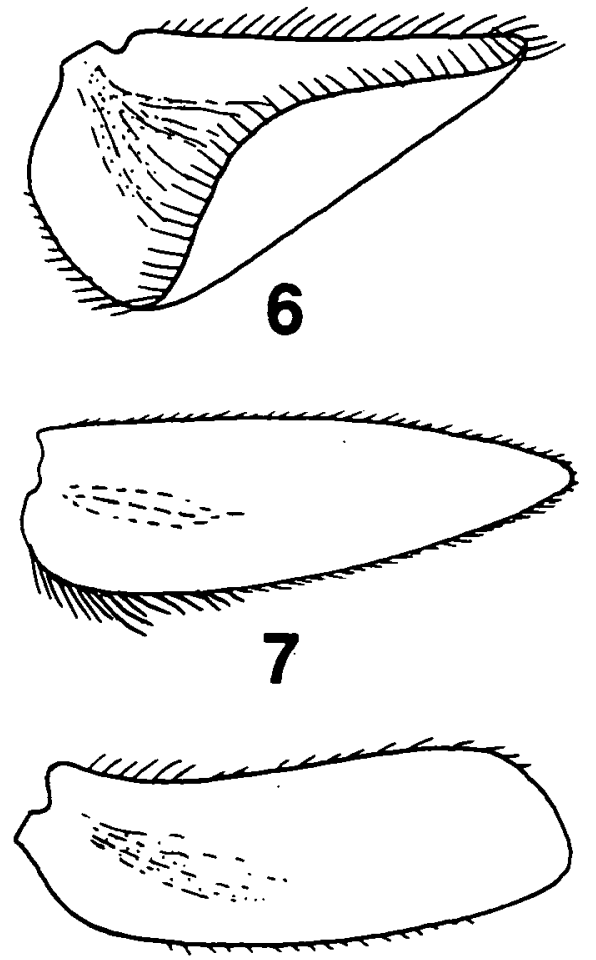

8

Fig. 2 to 10. Structures of Provonshaka thomasorum n.gen., n.sp., larvae. $2:$ galealacinia. $3:$ labium. $4:$ gill $1.5:$ gill $2.6:$ gill $3.7:$ gill 5.8 : gill 6. $9:$ Abdominal terga (mature, right half). $10:$ Abdominal terga (immature, right half).

Figs. 2 à 10. Structures larvaires de Provonshaka thomasorum n.gen., n.sp. $2:$ galealacinia. $3:$ labium. $4: 1^{e}$ branchie. $5: 2^{e}$ branchie. $6: 3^{e}$ branchie. $7: 5^{\circ}$ branchie. $8: 6^{6}$ branchie. $9:$ tergites abdominaux (larve mature : moitié droite). $10:$ tergites abdominaux (larve immature, moitié droite). 
Hindwingpads absent.

Tibiae (Fig. 1) with long hairlike setae.

Abdominal terga 7-10 (Fig. 1) with small spines along most of posterior margin. Terga 2 bluntly produced apicomedially. Terga 7-9 each with median elevated ridge produced into apex slightly exposed beyond posterior margin of tergum, and with dark submedian and sublateral stripes. Posterolateral projections on abdominal segments 5 and 8 strongly to slightly developed (Figs. 9, 10).

Alate stages : Unknown.

\section{Material examined}

Holotype : Female larva, Malagasy, Fianarantsoa Prov., Namarona Riv. $\left(22^{\circ} \mathrm{C}\right)$ at Ranomafana, 5-XI1971, G.F. and C.H. Edmunds, F. Emmanuel, deposited in the Purdue Entomological Research Collection. Additional material : one male larva and 2 female larvae, Malagasy, Fianarantsoa Prov., Tsaratango Riv. 9 km E Ranomafana, 6-XI-1971 ; 1 female larva, Malagasy, Tamatave Prov., Farimbony Riv. $\left(22^{\circ} \mathrm{C}\right)$ at R.N. $2,15-\mathrm{X}-71$. All additional material was collected by the holotype collectors and has the same deposition as the holotype.

\section{Species etymology}

This species is named after Alain and Nicole Thomas of Toulouse, France.

\section{Species characteristics}

There is some variability in the series before us, particularly regarding the development of the posterolateral projections on larval abdominal segments 5 and 8 (compare Figs. 9 and 10). The holotype, which is represented by a mature larva, possesses the much more developed projections shown in Figure 9. The other specimens were young to mid-instar larvae, and these did not show that same development (Fig. 10). This could be due to the age differential. On the other hand, the posterolateral projections on abdominal segments
6 and 7 are comparable among all of the specimens, and it is therefore possible that the differences in other segments are not related to age but are genetic differences associated with two different species. Until we have further data, we are taking the conservative approach to this problem, recognizing one variable species rather than two species.

\section{Generic relationships}

The arguments for placing Teloganella in the Tricorythidae instead of the Ephemerellidae (Teloganodinae) were outlined by Wang et al. (1995). Those same arguments apply to Provonshaka and Manohyphella. Provonshaka, Manohyphella, and Teloganella share the apomorphic posteriorly expanded larval femora. In Manohyphella and Teloganella, forewing veins CuA and ICuA are connected by a crossvein, and it appears quite possible that Provonshaka will also express this apomorphy. This lineage shares the reduction of segments in the male genital forceps and additional forewing venation apomorphies with the other Tricorythidae (again assumed for Provonshaka), and does not share any of the larval or adult apomorphies that delineate Ephemerellidae or Teloganodinae. Complete cladistic data will be forthcoming in our phylogenetic revision of the pannote mayflies.

\section{Acknowledgements}

We express special thanks to George F. Edmunds, Salt Lake City, Utah, for the donation of the material upon which this report was based, to Alain Thomas, Toulouse, France, for his valuable assistance ; and to Arwin Provonsha for the figures of $P$. thomasorum. This paper has been assigned Purdue Agricultural Research Program Journal Number 14668 .

\section{References}

Allen R.K. 1973. - New Ephemerellidae from Madagascar and Afghanistan. Pan-Pac. Entomol., 49 (2) : 160-164.

Demoulin G. 1968. - Quelques Ephéméroptères nouveaux de Madagascar. II. Bull. Inst. r. Sci. nat. Belg., 44 (32) : 1-9.

Wang T.-Q., McCafferty W.P. \& G.F. Edmunds, Jr. 1995. — Larvá and adult of Teloganella (Ephemeroptera : Pannota) and assessment of familial classification. Ann. entomol. Soc. Am., 88 (3) . 324-327. 